\begin{tabular}{l} 
MISCELLANEA \\
GEOGRAPHICA \\
\hline
\end{tabular}

Vol. $13 / 2008$

pp. $113-120$

\title{
Katarzyna Pietras
}

\author{
University of Warsaw - Faculty of Geography and Regional Studies - Department of Climatology \\ 00-927 Warsaw, Krakowskie Przedmieście 30 \\ e-mail: migi4@op.pl

\section{DAILY OSCILLATIONS OF THE AIR TEMPERATURE IN SELECTED CONIFEROUS COMMUNITIES IN THE BORECKA FOREST}

\begin{abstract}
Two coniferous forest communities were selected for analysis: a marshy coniferous forest and a young spruce forest, both located in the Borecka Forest. Thermal conditions develop differently in each community during the spring, due to different tree crown closure, which influences the amount of direct solar radiation reaching the substratum. Soil humidity is another factor influencing the air temperature, since the capacity and thermal inertia of the soil depend on its humidity. The results of the study are compared with thermal conditions outside the forest.
\end{abstract}

Key words: air temperature, amplitude, maximal air temperature, minimal air temperature, local climate

Since 1 February 2007, studies of the influence of coniferous communities on the local climate have been conducted in the Borecka Forest [Puszcza Borecka]. They constitute a research project financed for the years 2006-2007.

Since the climate inside a forest is very varied - as a result of the complicated structure of the forest stand - Bednarek (1979) recommends that special measurement networks be organized in forest regions. The network in the Borecka Forest consists of six sites. Five of them are located in forest communities with varied species composition, varied crown closure, density of undergrowth and forest floor, and substratum humidity. These are: mixed fresh forest, marshy coniferous forest, dry-ground forest, alder carr, and young spruce for- 
est. The sixth measurement point is localized in an open field, about $1.5 \mathrm{~km}$ west of the forest border. The data collected there are used as background for any analysis of the subcanopy climate.

At each point, at $0.25 \mathrm{~m}, 2.0 \mathrm{~m}$, and $5.0 \mathrm{~m}$ above ground, electronic measuring instruments EBI-20-TH have been located under a special roofing. Each 10 minutes, the instruments measure and register temperature as well as relative air humidity. Based on that, the maximal and the current water damp pressure, as well as the absolute humidity are calculated. Further analyses of the local climate are conducted on the basis of data from measurements and calculated data.

For this paper, two forest communities have been selected. One of them is the marshy coniferous forest, with low crown closure and fairly low density of undergrowth and forest floor, characterized by very high substratum humidity. The other one is a young spruce forest, a community with high crown closure, a subcanopy stratum filled with dry branches, without undergrowth or forest floor. The substratum there has low humidity.

The third research area used in analysis is the open field. It is characterized by high wind velocity, unlimited inflow of the direct solar radiation during the day and by large heat losses during the night (longwave loss). In the winter, the substratum there was not covered with snow (as opposed to the forest measurement points), and as a result, small amount of water was supplied to the soil during the thaw. At this point, the warming of the soil surface started earlier than at the points located within the Borecka Forest.

The analysis was conducted for three months: March, April and May, defined commonly in climatology as the spring season (Niedźwiedź 2003).

In March, the average daily air temperature varied relatively little from day to day. The largest oscillations were observed between the 20 and 21 March: they were equal to $5.6^{\circ} \mathrm{C}$ in the young spruce forest (the point with smallest oscillations), $6.3^{\circ} \mathrm{C}$ in the marshy coniferous forest, and $7.5^{\circ} \mathrm{C}$ in the open field. In the last-named place, the oscillations of the average daily air temperature were largest during the entire month.

Until the time when the snow cover disappeared, the largest oscillations of the average daily temperature amplitude and the average daily air temperature had occurred at $5.0 \mathrm{~m}$ above the ground level, while after the disappearance of the snow cover, the oscillations of 
thermal conditions were much larger at the ground surface. This did not, however, occur at the measurement point representing the open field, because this place was not covered with snow during the entire time of the study project.

The value of the air temperature changes from day to day is demonstrated by its extreme values. During the whole month, the highest minimal values occurred in the young spruce forest, where the temperature did not fall below $-1.7^{\circ} \mathrm{C}$. The smallest changes from day to day occurred also at that point (the maximal value, $-4.1^{\circ} \mathrm{C}$, occurred from 20 to $21 \mathrm{March})$. The absolute minimal air temperature $\left(-2.4^{\circ} \mathrm{C}\right)$ was observed in the marshy coniferous forest. Changes in minimal temperature in the marshy coniferous forest reached $5.6^{\circ} \mathrm{C}$; as in the young spruce forest, they occurred also from 20 to 21 March. At the same time, the oscillations of the minimal temperature in the open field reached their largest observed value, that is, $8.8^{\circ} \mathrm{C}$.

During the whole month, the lowest maximal values of air temperature were observed in the young spruce forest, where the highest temperature reached $13.3^{\circ} \mathrm{C}$, on 13 March. The highest maximal temperature occurred in the marshy coniferous forest: for instance, on $28 \mathrm{March}$ the temperature rose to $28.2^{\circ} \mathrm{C}$. On the same day in the open field the maximal temperature was only $17.5^{\circ} \mathrm{C}$.

The changes of the daily amplitude of air temperature in March, as measured from one day to another, were small. In the young spruce forest they were no larger than $3.6^{\circ} \mathrm{C}(16 / 17 \mathrm{March})$, in the marshy coniferous forest they reached $7.2^{\circ} \mathrm{C}(5 / 6 \mathrm{March})$; but the largest oscillations of this thermal feature occurred in the open field, where they were over $7.5^{\circ} \mathrm{C}$ on several days, and their maximal value reached $13.3^{\circ} \mathrm{C}(13 / 14 \mathrm{March})$.

In April, daily oscillations of all the thermal features mentioned above were larger than in March. The only exception was the young spruce forest, where on 9/10 April the maximal air temperature was $4.0^{\circ} \mathrm{C}$ and did not change.

The value of the changes in the average daily air temperature was similar at all measurement points in April. It oscillated between $0.2^{\circ} \mathrm{C}$ on $13 / 14$ April and $6.6^{\circ} \mathrm{C}$ on $17 / 18$ April in the young spruce forest. In the marshy coniferous forest, the daily changes oscillated between $0.1^{\circ} \mathrm{C}$ on $18 / 19$ April to $7.0^{\circ} \mathrm{C}$ on $17 / 18$ April. In the open field, the smallest change, $0.1^{\circ} \mathrm{C}$, occurred on $12 / 13$ April, and the largest change, $6.8^{\circ} \mathrm{C}$, on $17 / 18$ April. 
Similarly, the minimal daily air temperature changed little at the beginning. During the first week of the month the changes in the marshy coniferous forest were below $1.7^{\circ} \mathrm{C}$; in the young spruce forest they were below $2.5^{\circ} \mathrm{C}$, and in the open field they were slightly larger than $2.0^{\circ} \mathrm{C}$. Later, the daily changes increased significantly, and reached $7.5^{\circ} \mathrm{C}$ on $23 / 24$ April in the marshy coniferous forest. At the same time, in the young spruce forest, the minimal temperature changed by $5.0^{\circ} \mathrm{C}$, and in the open field, by as much as $8.8^{\circ} \mathrm{C}$.

In April, as in March, the highest minimal air temperature was observed in the young spruce forest during the entire month; they oscillated between $-2.5^{\circ} \mathrm{C}$ on 7 April and $9.3^{\circ} \mathrm{C}$ on 27 April. The lowest minimal temperature was observed in the open field: it was in the interval between $-8.1^{\circ} \mathrm{C}$ on 7 April and $6.5^{\circ} \mathrm{C}$ on 28 April.

The maximal values of air temperature were highest also at the end of April. In this month, as in March, the lowest maximal values occurred in the young spruce forest (from $2.0^{\circ} \mathrm{C}$ on 8 April to $19.1^{\circ} \mathrm{C}$ on 27 April). In the marshy coniferous forest, the maximal value was, at the beginning, larger than in the open field by as much as $5.0^{\circ} \mathrm{C}$, but after 20 April, higher maximal temperature values occurred in the open field. (On 26 April the difference reached even as much as $8.2^{\circ} \mathrm{C}$.)

The range of the oscillations of the maximal daily temperature was much larger than in the case of the minimal daily temperature. On $17 / 18$ April, it reached $10.2^{\circ} \mathrm{C}$ in the young spruce forest, $14.3^{\circ} \mathrm{C}$ in the marshy coniferous forest, and $17.4^{\circ} \mathrm{C}$ in the open field.

In the case of daily amplitudes of air temperature, during the whole April, changes remained on the same level. The smallest values, both of amplitude and of its day-to-day changes, occurred in the young spruce forest. The largest amplitude, $13.7^{\circ} \mathrm{C}$, was recorded at this site on 15 April; the maximal change, $6.5^{\circ} \mathrm{C}$, occurred on $17 / 18$ April. The values of the amplitude in the marshy coniferous forest and in the open field were similar in the first half of the month. Later, however, they decreased in the marshy coniferous forest and were lower than in the open field by ca. $3.5^{\circ} \mathrm{C}$.

In May, the last month under investigation, day-to-day changes of both the average daily air temperature and of its extreme values, as well as of the daily amplitude of temperature, were lower than in April.

The average daily air temperature at all points was increasing with time from $2.4^{\circ} \mathrm{C}$ on 1 May to $20.6^{\circ} \mathrm{C}$ on 29 May in the young spruce forest; from $3.4^{\circ} \mathrm{C}$ on 1 May to $21.9^{\circ} \mathrm{C}$ on 28 May in the marshy conif- 
erous forest; and from $3.4^{\circ} \mathrm{C}$ on 1 May to 23.6 on 28 May in the open field. The daily changes did not exceed $7.0^{\circ} \mathrm{C}$ in the marshy coniferous forest (on $15 / 16 \mathrm{May}$ ), and, at the same time, $6.6^{\circ} \mathrm{C}$ in the young spruce forest and $7.1^{\circ} \mathrm{C}$ in the open field.

In May, the minimal daily temperature was increasing from values below zero $\left(-2.6^{\circ} \mathrm{C}\right.$ in the marshy coniferous forest, $-1.4^{\circ} \mathrm{C}$ in the young spruce forest, and $-4.6^{\circ} \mathrm{C}$ in the open field on 2 May) to $15.9^{\circ} \mathrm{C}$ on 26 May in the marshy coniferous forest, $16.5^{\circ} \mathrm{C}$ on 29 May in the young spruce forest and on 26 May in the open field. At both forest measurement points the daily minimal temperature had a similar value, whole at the open-field point they were lower during the entire month.

The range of oscillations of the daily minimal temperature in May was similar at all three points. It changed from $0.2^{\circ} \mathrm{C}$ in the young spruce forest and the marshy coniferous forest, and from $0.6^{\circ} \mathrm{C}$ in the open field (on 14 May) to $7.5^{\circ} \mathrm{C}$ in the marshy coniferous forest, $4.1^{\circ} \mathrm{C}$ in the young spruce forest, and $9.0^{\circ} \mathrm{C}$ in the open field (on 25 May).

In accordance with the tendency observed during the entire threemonth period, the lowest maximal value of the temperature occurred in the young spruce forest: on 26 May it slightly exceeded $26.0^{\circ} \mathrm{C}$. On the same day, the maximal temperature on the marshy coniferous forest reached $28.7^{\circ} \mathrm{C}$, while on 28 May the temperature in the open field was as high as $34.7^{\circ} \mathrm{C}$.

The changes of the daily maximal temperature on 15/16 May were equal to $10.0^{\circ} \mathrm{C}$ in the marshy coniferous forest, and $8.2^{\circ} \mathrm{C}$ in the young spruce forest; on $22 / 23$ May, they were equal to $12.9^{\circ} \mathrm{C}$ in the open filed. The smallest changes of the daily changes of the maximal daily temperature were observed on 10/11 May in the marshy coniferous forest $\left(0.2^{\circ} \mathrm{C}\right)$, on $4 / 5$ May on the young spruce forest $\left(1.0^{\circ} \mathrm{C}\right)$, and in 7 May in the open field $\left(0.6^{\circ} \mathrm{C}\right)$.

In the marshy coniferous forest the average monthly temperature amplitude in May was equal to $11.6^{\circ} \mathrm{C}$, in the young spruce forest it was equal to $7.8^{\circ} \mathrm{C}$, and in the open field it was $17.5^{\circ} \mathrm{C}$. Despite of large differences at all measurement points, this thermal feature has a similar development over the month.

In the young spruce forest, the changes of daily temperature amplitude on day-to-day basis were smallest and did not exceed $5.5^{\circ} \mathrm{C}$ on 15/16 May. The largest changes occurred in the open field, where they were reached $13.0^{\circ} \mathrm{C}$ on $18 / 19$ May.

The above examples can be summarized as follows. 
The vegetation played the dominating role in the formation of thermal conditions at the selected sites. The fundamental factor that modified the air temperature was the crown closure. This influenced the amount of solar radiation directly reaching the substratum during the day and, also, the amount of heat loss during the night. Similar effects were observed by Olszewski (1986), Tomanek (1980) and Sapożnikowa (1953). In the young spruce forest, the canopy caused the lowest maximal values and the highest minimal values of temperature to occur, and therefore, the smallest daily amplitudes of air temperature. The mitigating influence of the dense tree canopy was visible also in the smallest day-to-day changes of all the thermal characteristics described in this paper. Such conditions remained in the young spruce forest during the entire period under investigation, since in this forest community the foliage degree does not change, in principle, depending on the phenologic season.

An opposite situation occurred in the open field, where scarce vegetation did not limit the inflow of radiant energy during the day or of heat loss from the substratum. (Similar conclusions, based on field research, were drawn by Gumiński (1951) and Sapożnikowa (1953)). For this reason, the changes of maximal, minimal, and daily average temperature, as well as of day-to-day amplitude of temperature were largest there. Relatively high extreme values of temperature were observed also outside the forest.

An interesting situation occurred in the marshy coniferous forest, where at the beginning, the vegetation was weakly developed, and thus it allowed for large amounts of radiant energy during the day; after the sunset it did not protect the substratum from heat loss. (This agrees with observations made by Olszewski (1986).) At that time, absolute maximal and minimal values, as well as largest daily amplitudes of air temperature were observed on this site. Thermal conditions in the marshy coniferous forest changed after the vegetation in the subgrowth and forest floor - covering the substratum - had developed. From that time on, the maximal temperature became lower, and the minimal temperature, higher than outside the forest. Moreover, the daily temperature amplitudes decreased, as did the average daily temperature. The range of the daily changes of all the air temperature characteristics under investigation also decreased.

The temperature was modified not only under the influence of the tree closure. As was stated by Tomanek (1980), the influence of the 
vegetation on wind velocity is also important. At forest sites, wind velocity was always smaller than outside the forest. Thanks to that, the air could stagnate and therefore, while being in contact with the substratum, it could undergo warming (during the day) or cooling (during the night) for a longer period. Because of that, the temperature observed in the marshy coniferous forest during the day was considerably higher than in the open field, while during the night, it was considerably lower.

The substratum characteristic was another factor, after vegetation, which influenced the daily changes of air temperature. In the marshy coniferous forest very low values of minimal temperature were observed in March and April, because the soil at this site contained large amounts of water. Thus, the soil temperature increased more slowly after the winter chill than in the case of dry soils at the two other sites (cf. for example Sapożnikowa 1953). The joint effect of the influence of the substratum - cooled during the winter - and the heat loss at night results in a particularly large temperature decrease.

One should also mention the snow cover, remaining at the two forest sites during the first half of March. At that time, the changes of all the thermal characteristics under investigation were smaller at the ground level than at $5.0 \mathrm{~m}$ above ground. Also, the daily minimal temperature was higher, while the daily maximal temperature, lower. As a result, the range of the daily temperature changes was smaller. When the snow cover disappeared, the values of extreme temperature at ground level increased, and all the day-to-day changes had greater range. This shows that the snow cover has a mitigating influence on thermal characteristics (similarly to the results obtained by Sapożnikowa). In the open field such correlation was not observed, since the snow cover was blown off by wind.

The studies discussed above constitute a part of a much longer observation series and confirm the conjecture that vegetation has a significant influence on the local climate conditions.

\section{REFERENCES}

Bednarek A., Huculak W., Makowiec M., 1979, Materiaty do ćwiczeń z meteorologii i klimatologii leśnej [Workbook of Meteorology and Forest Climatology; in English], Wydawnictwo SGGW-WR, Warszawa. 
Gumiński, R., 1951, Las jako czynnik makroklimatyczny [The Forest as a Macroclimatic Factor; in Polish], Wiadomości Stużby Hydrologicznej i Meteorologicznej, t. 3, z. 2, Warszawa.

Niedźwiedź T. (ed.), 2003, Stownik meteorologiczny [Meteorological Dictionary; in Polish], Polskie Towarzystwo Geofizyczne IMGW, Warszawa.

Olszewski, J. L., 1986, Rola ekosystemów leśnych w modyfikacji klimatu lokalnego Puszczy Białowieskiej [The Role of Forest Ecosystems in Modification of the Local Climate in the Białowieska Forest; in Polish], Ossolineum, Warszawa.

Tomanek, J., 1980, Meteorologia i klimatologia dla leśników [Meteorology and Climatology for Foresters; in Polish], PWRiL, Warszawa.

Sapożnikowa, S., 1953, Mikroklimat i klimat lokalny [Microclimate and Local Climate; in Polish], PWRiL, Warszawa.

English translation: Matgorzata Mikulska 